\title{
Chronic Recurrent Multifocal Osteomyelitis: Treatment with a Tumor Necrosis Factor-Alpha Inhibitor
}

\author{
Kronik Tekrarlayan Multifokal Osteomiyelit: Tümör Nekroz Faktör-Alfa İnhibitörü Tedavisi
}

\author{
André de Souza CAVALCANTI, Evaldo Gomes SENA, Sérgio Vasconcelos CAVALCANTI, \\ Fernando de Souza CAVALCANTI, Ângela Luzia Branco Pinto DUARTE \\ Federal University of Pernambuco, Department of Clinical Medicine, Recife, Pernambuco, Brazil
}

\begin{abstract}
Chronic recurrent multifocal osteomyelitis (CRMO), a non-bacterial osteitis (NBO), is a rare auto-inflammatory immune disorder. A delay in the diagnosis of this disease may cause irreversible damage to the skeletal system. The similarities among CRMO, Majeed syndrome, and chronic multifocal osteomyelitis (CMO) in mice strongly indicate a genetic basis. In this article, we present a 10-year-old boy with CRMO who was successfully treated with a tumor necrosis factor-alpha (TNF- $\alpha$ ) inhibitor after conventional management had failed. Over a five-year period, he had experienced intermittent pain in his joints and been treated with non-steroidal anti-inflammatory drugs (NSAIDs). In a search for the cause of these symptoms, he was admitted to a pediatric orthopedic unit where he was diagnosed as having septic osteomyelitis. He underwent treatment with several antibiotics, however no improvement was seen and he was referred to a pediatric rheumatologist. Magnetic resonance imaging (MRI) and X-rays were crucial in the patient's diagnosis. This case serves as an example of the need to emphasize prompt referrals for patients suspected of having CRMO so as to avoid bone damage and provide adequate management.
\end{abstract}

Key words: Chronic recurrent multifocal osteomyelitis; nonbacterial osteitis; tumor necrosis factor.

Chronic recurrent multifocal osteomyelitis (CRMO) is an autoinflammatory, autosomal-recessive immune disease that was first described in 1972. It has a female to male ratio of 4:1, and 260 cases have been reported. ${ }^{[1]}$ This disease is characterized by bone pain and fever caused by non-infectious agents, and it has a course of recurrent flare-ups followed by spontaneous remissions. ${ }^{[1,2]}$
Bakteriyel olmayan osteit (NBO) olan kronik tekrarlayan multifokal osteomiyelit (CRMO), nadir görülen otoinflamatuvar immün bozukluğudur. Hastalığın tanısında gecikme, iskelet sisteminde geri dönüşü olmayan hasara yol açabilir. Kronik tekrarlayan multifokal osteomiyelit, Majeed sendromu ve farelerde kronik multifokal osteomiyelit (CMO) arasındaki benzerlikler, kuvvetli bir şekilde genetik zemine işaret etmektedir. Bu yazıda konvansiyonel tedavi başarısızlıkla sonuçlandıktan sonra, tümör nekroz faktöralfa (TNF- $\alpha$ ) inhibitörü ile başarılı bir şekilde tedavi edilen 10 yaşında bir erkek CRMO olgusu sunuldu. Beş yıllı aşkın bir süreyle hastanın eklemlerinde aralıklarla ağrı seyrediyordu ve hasta nonsteroid antiinflamatuvar ilaçlar (NSAii) ile tedavi edildi. Semptomların nedenini araştırmak üzere, hasta pediatri ve ortopedi servisine yatırıldı, septik osteomiyelit tanısı kondu. Çeşitli antibiyotikler ile tedavi edildi, ancak durumunda hiçbir iyileşme görülmeyince, hasta bir pediatrik romatoloji uzmanına sevk edildi. Bu olgunun tanısında manyetik rezonans görüntüleme (MRG) ve röntgen çok önemliydi. Bu olgu, CRMO şüphesi taşıyan hastalarda kemik hasarını önlemek ve yeterli düzeyde tedavi sağlamak için hızlı sevk ihtiyacını vurgulamak için bir örnek teşkil etmektedir.

Anahtar sözcükler: Kronik tekrarlayan multifokal osteomiyelit; bakteriyel olmayan osteoit; tümör nekroz faktör.

Chronic recurrent multifocal osteomyelitis is considered the pediatric version of the synovitis, acne, pustulosis, hyperostosis, osteitis (SAPHO) syndrome. ${ }^{[3]}$

The etiology of CRMO remains unclear. It is known that infections, immune deficiency, and autoimmunity are unlikely causes. The similarity with Majeed syndrome, an autosomal disorder, ${ }^{[4]}$ and chronic

Received: February 14, 2012 Accepted: May 18, 2012

Correspondence: Fernando de Souza Cavalcanti, M.D. Universidade Federal de Pernambuco, Medicina Clinica, Recife/Pernambuco, Brazil.

Tel: 55813454.0155 e-mail: fsc51@uol.com.br

(C)2012 Turkish League Against Rheumatism. All rights reserved. 


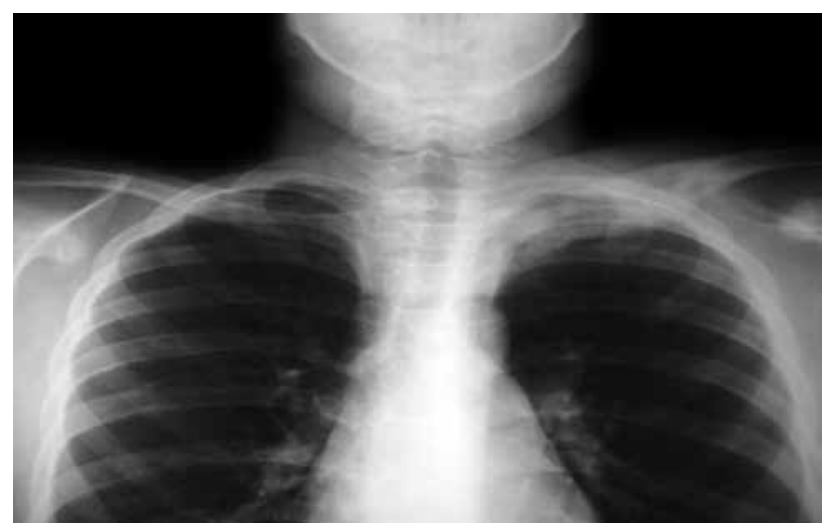

Figure 1. A chest X-ray showed bone enlargement on the left clavicle.

multifocal osteomyelitis (CMO) in mice, ${ }^{[5]}$ suggests a genetic origin. Mutations in LPIN2 cause a syndromic form of CRMO, and mutations in proline-serinethreonine phosphatase interacting protein 2 (PSTPIP2) cause a murine form of the disorder. ${ }^{[4,5]}$

It is unclear how best to manage CRMO as there have been few randomized trials. Non-steroidal antiinflammatory drugs (NSAIDs) are considered to be the first line of therapy. Corticosteroids have also been utilized with relative success; however, their side effects limit their use. In addition, disease-modifying antirheumatic drugs (DMARDs), especially those

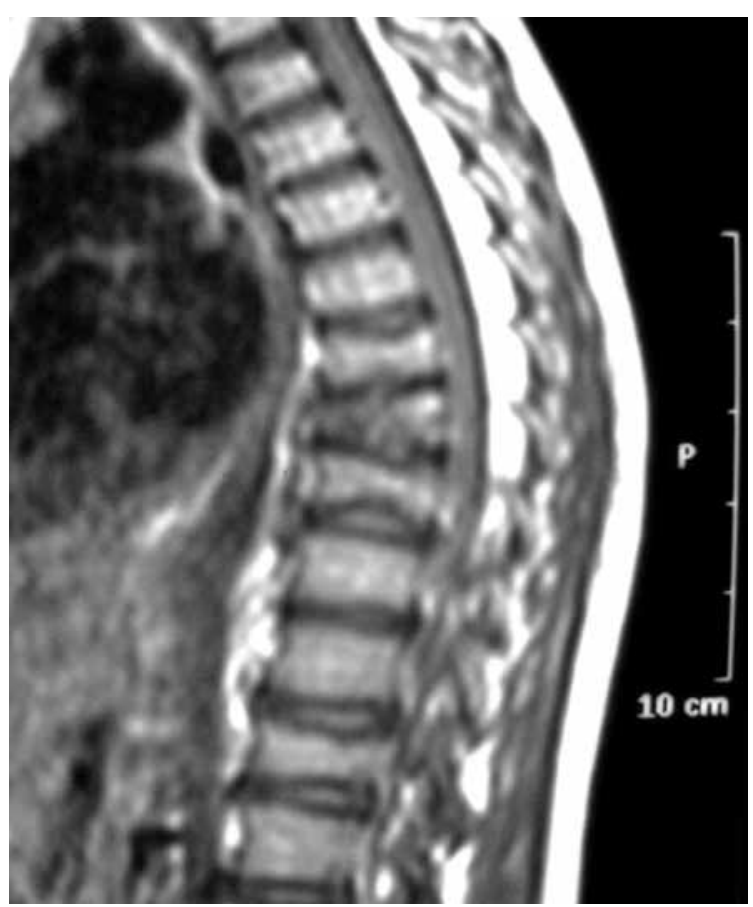

Figure 3. A thoracic magnetic resonance imaging showed inflammatory bone lesions on T7-T9.

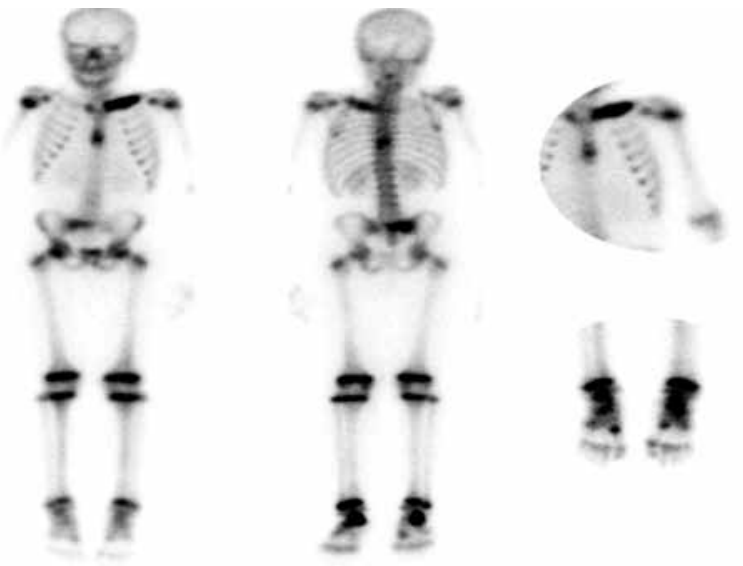

Figure 2. A bone scan (technetium-99m) revealed an increased uptake on the left clavicle, thoracic spine, sacroiliac joints, and left ankle.

with steroids, have been prescribed for patients with more severe manifestations. ${ }^{[6]}$ We report the use of a tumor necrosis factor-alpha (TNF- $\alpha$ ) inhibitor in a patient unresponsive to other treatments who had been suffering from CRMO.

\section{CASE REPORT}

A 10-year-old boy was referred to the Pediatric Rheumatology Unit at the University Hospital Federal University of Pernambuco, Recife in 2008 with a fiveyear history of intermittent pain in his left clavicle, right hip, ankles, and dorsal spine. In 2006, he was admitted to the Pediatric Unit complaining of back pain, fever, and a mass over his left clavicle. Blood tests showed a C-reactive protein (CRP) level of $24 \mathrm{mg} / \mathrm{dl}$ and an erythrocyte sedimentation rate (ESR) of $39 \mathrm{~mm} / \mathrm{h}$. A chest X-ray confirmed the mass over his left clavicle (Figure 1). Septic osteomyelitis was diagnosed, although his blood and bone cultures were negative. A course of an empirical antibiotic (cephalothin) and NSAIDs was prescribed. He was later referred (after one year) to the Orthopedic Unit where a thoracic computed tomography (CT) scan showed the volume of the left clavicle had increased due to an area of hyperostosis mixed with osteolysis. Hence, the antibiotic was changed to ciprofloxacin for three months. As there was no improvement, he was referred to the Pediatric Rheumatology Unit, where a tuberculin test and ANA were negative. A bone scan showed an increased technetium-99m $(99 \mathrm{mTc})$ radioisotope uptake at the left clavicle, ankle, sacroiliac joints, and $\mathrm{T}_{8}$ thoracic disc (Figure 2). Magnetic resonance imaging (MRI) demonstrated multiple inflammatory lesions between the $\mathrm{T}_{7}$ and $\mathrm{T}_{9}$ disks (Figure 3 ) and in the left clavicle 


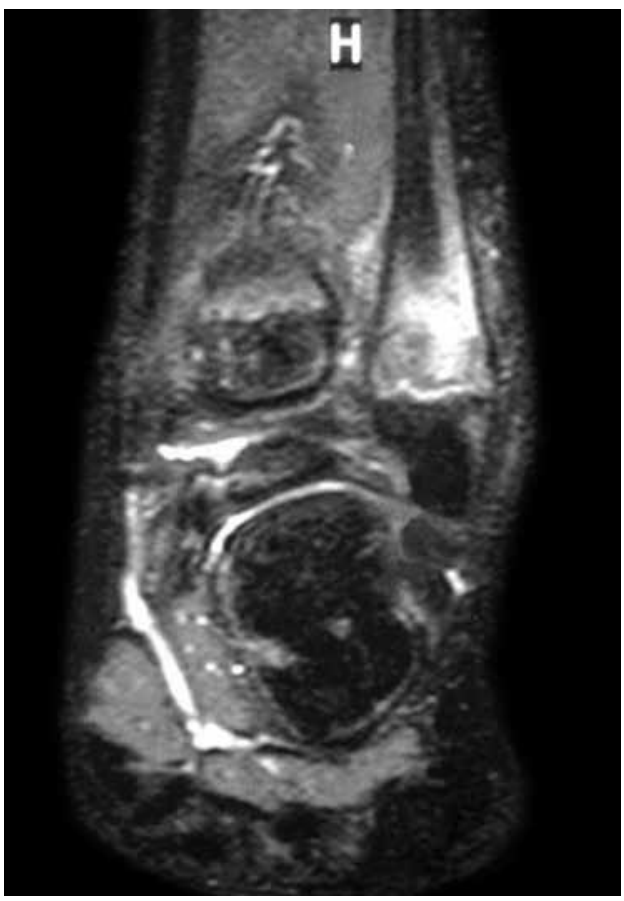

Figure 4. A left leg magnetic resonance imaging demonstrated osteolytic lesion changes on the left distal tibial metaphysis.

and left ankle (Figure 4), thus confirming the findings on the bone scan and thorax CT. The results of the histological analysis of a bone biopsy were compatible with aseptic chronic osteomyelitis (Figure 5). No infection was identified by lesion or blood culture, and no malignancy was detected by imaging; hence, the possibility of CRMO was raised. An aggressive treatment with NSAIDs, alendronate $70 \mathrm{mg} / \mathrm{week}$, methotrexate $15 \mathrm{mg} /$ week, and infliximab $5 \mathrm{mg} / \mathrm{kg}$ was initiated due to the severity of the case and the delay in diagnosis. After the third infusion of infliximab, the boy became free of pain. His ESR and CRP levels were normal, and a bone scan showed a tiny uptake at the left clavicle. It should be noted that the patient and his family gave their consent for any treatment provided at the Pediatric Rheumatology Unit.

The patient is now doing well and growing at a normal rate. This report emphasizes the importance of referring children with unexplained joint pain and fever to a pediatric rheumatologist for an early diagnosis so that appropriate treatment can begin as soon as possible.

\section{DISCUSSION}

Having sterile bone lesions with non-specific signs of inflammation is a feature shared by several

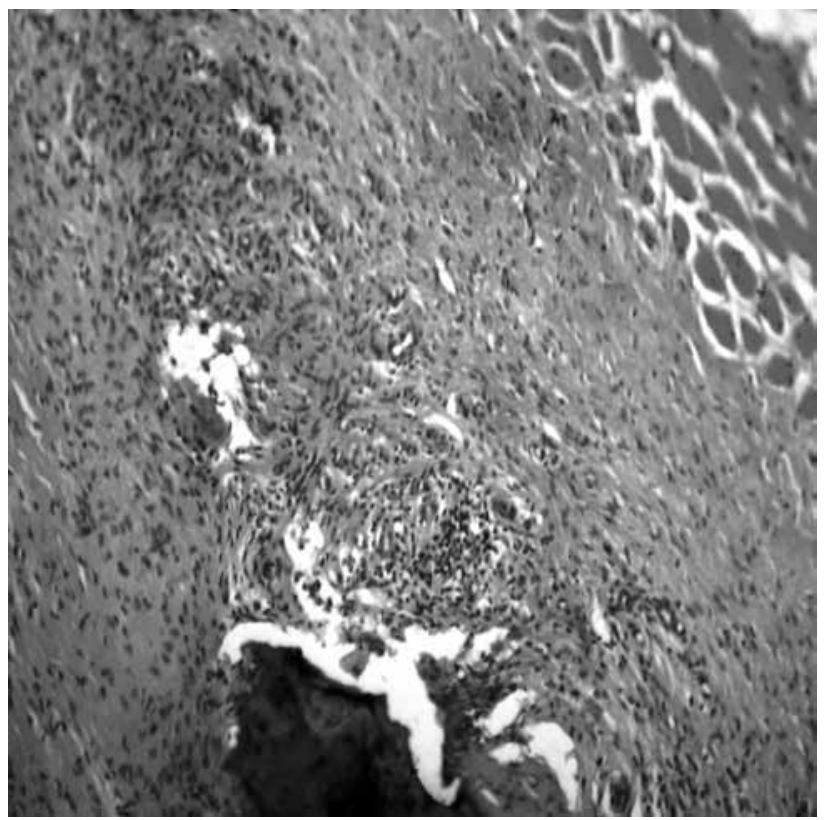

Figure 5. Foreign body granuloma (H-E x 10).

disorders. ${ }^{[1]}$ They are recurrent in nature ${ }^{[4]}$ and are often associated with comorbid inflammatory disorders. ${ }^{[1,2,4,7]}$ Involvement of other organs has been reported; ${ }^{[8,9]}$ however, in this case, the simultaneous bouts of pain were restricted to multiple bone locations: the pelvis, clavicle, vertebrae, and both legs. Eighty-five percent of the CRMO cases have occurred in girls with a median onset age of 10 years old. The most common manifestations are fever accompanied by bone pain and signs of inflammation in the soft tissues around the border of the affected regions. ${ }^{[1,2]}$ The early literature suggested CRMO was self-limiting in most cases but that it could last as long as 15 years. ${ }^{[2]}$ At present, the median duration of activity is 2.7 years, and the median time between the first symptom and diagnosis is 9.2 months (range, 1-26 months). ${ }^{[7]}$ In this case, there was a five-year delay before a definitive diagnosis was made.

Elevated TNF- $\alpha(>25 \mathrm{pg} / \mathrm{ml})$ occurs in $66 \%$ of cases of CRMO, ${ }^{[1]}$ and an increase in acute phase protein ${ }^{[1,2]}$ suggests a flare-up. Blood and bone cultures are negative, including tests for mycobacterium and mycoplasma. ${ }^{[10]}$ Our patient had a slight increase in ESR, negative blood and bone marrow cultures, and a negative test for tuberculosis.

An X-ray can show areas of osteolysis at the metaphysis and diaphysis as well as the sclerosis around it. ${ }^{[10,11]}$ Bone scans $(99 \mathrm{mTc}), \mathrm{CT}$, and MRIs can help in the diagnosis by determining the location for a bone biopsy and assessing the activity of the disease. ${ }^{[1]]}$ The 
X-ray and MRI images were of great importance in our case since they provided evidence of the osteolysis and bone enlargement lesions. ${ }^{[12,13]}$ Vertebral compression is a rare radiographic finding, but an MRI revealed compressive lesions of the spine at $\mathrm{T}_{7}-\mathrm{T}_{9}$ along with scoliosis in our patient. His pain was lessened after he was treated with NSAIDs.

No similarity exists between CRMO and tuberculous spondylitis, in which infection begins on the anterior parts of vertebral bodies and progresses to the intervertebral disc. Areas of bone destruction are well defined in tubercular spondylitis, and a paraspinal abscess is formed that may extend to the psoas muscle.

A bone biopsy is necessary for the differential diagnosis of CRMO in order to exclude malignancy and infection, and pyogenic osteomyelitis, if found, is a reliable indicator of this disease. Usually an extensive microbial investigation (including tissue culture and serology) should be conducted since treatment with antibiotics is ineffective. However, improvement in patients treated with azithromycin has been reported, but this can be attributed to its anti-inflammatory effect. ${ }^{[14]}$ The biopsy of the clavicle in our case showed a chronic inflammatory reaction like that of a foreign body granuloma.

Little is known about the function of the gene LPIN2 $2^{[4]}$ in Majeed syndrome, but its mutations could lead to the production of more pro-inflammatory signals. In turn, this disrupts the gene's function in self-regulating oxidative stress (OS), leading to an auto-inflammatory process with tissue damage. ${ }^{[4]}$ This defect affects the innate immune system due to the dysregulation of a pathway that is important in bone and skin inflammation. ${ }^{[5]}$

The empirical diagnostic criteria for CRMO includes the following: multifocal bone lesions, a clinical course extended for months with remissions and exacerbations, a lack of response to antimicrobial treatment, and osteolytic-sclerotic bone lesions on $\mathrm{X}$-ray. ${ }^{[10]}$ Compliance with all of the criteria is required for a definitive diagnosis. ${ }^{[10]}$ Jansonn et al. ${ }^{[1]}$ undertook a retrospective analysis of 89 patients and drew up diagnostic criteria for non-bacterial osteitis (NBO), but these have not yet been validated.

There is no specific treatment for CRMO, although the symptoms usually regress with NSAIDs with $80 \%$ efficacy. ${ }^{[6,13]}$ Physical therapy of the impaired segment should be considered as soon as possible. Corticosteroids have been used in multifocal relapsing cases, and improvement was seen. ${ }^{[15]}$ Interferon- $\alpha$ and $\gamma$ have been used in a few patients with CRMO, and some improvement was noted. Bisphosphonates have also used, especially pamidronate ${ }^{[16]}$ since it has antiresorptive and anti-inflammatory actions. Progress has also been attained with the use of TNF- $\alpha$ blockers such as infliximab which reportedly promotes healing in the inflammatory lesion. ${ }^{[1]}$ Although the study involving TNF- $\alpha$ was not placebo-controlled, sufficient evidence still exists to justify the use of bisphosphonates and TNF- $\alpha$ blockers ${ }^{[1]}$ in for the treatment of CRMO when the use of NSAIDs and steroids has failed.

In this case, the boy's condition partially responded to the use of NSAIDs. However, with a view toward discovering a more effective management approach, a combination of infliximab, which was employed in a similar manner to how it is used in the treatment of rheumatoid arthritis (RA), and alendronate was started. Methotrexate was also prescribed to prevent antibodies against infliximab,. Unfortunately, the small number of clinical trials involving CRMO limits the use of new management approaches.

A follow-up study on 23 children with CRMO over a five-year period showed that most were able to complete their schooling, get jobs, and have some emotional stability. ${ }^{[17]}$ However, CRMO is not a benign disease, and numerous bone sequels, such as growth retardation, thoracic scoliosis, and bone deformities, have been seen.

Although in this case there were no bone sequelae or growing defect, more clinical trials are needed to further investigate CRMO. Perhaps with further research, new treatment methods can be put into practice to reduce the effects of this disease.

\section{Declaration of conflicting interests}

The authors declared no conflicts of interest with respect to the authorship and/or publication of this article.

\section{Funding}

The authors received no financial support for the research and/or authorship of this article.

\section{REFERENCES}

1. Jansson A, Renner ED, Ramser J, Mayer A, Haban M, Meindl A, et al. Classification of non-bacterial osteitis: retrospective study of clinical, immunological and genetic aspects in 89 patients. Rheumatology (Oxford) 2007;46:154-60. 
2. Catalano-Pons C, Comte A, Wipff J, Quartier P, Faye A, Gendrel D, et al. Clinical outcome in children with chronic recurrent multifocal osteomyelitis. Rheumatology (Oxford) 2008;47:1397-9.

3. Kahn MF. Current status of the SAPHO syndrome. Presse Med 1995;24:338-40. [Abstract]

4. Al-Mosawi ZS, Al-Saad KK, Ijadi-Maghsoodi R, El-Shanti HI, Ferguson PJ. A splice site mutation confirms the role of LPIN2 in Majeed syndrome. Arthritis Rheum 2007;56:960-4.

5. Chitu V, Ferguson PJ, de Bruijn R, Schlueter AJ, Ochoa LA, Waldschmidt TJ, et al. Primed innate immunity leads to auto-inflammatory disease in PSTPIP2-deficient cmo mice. Blood 2009;114:2497-505.

6. Girschick HJ, Raab P, Surbaum S, Trusen A, Kirschner S, Schneider P, et al. Chronic non-bacterial osteomyelitis in children. Ann Rheum Dis 2005;64:279-85.

7. Kerem E, Manson D, Laxer RM, Levison H, Reilly BJ. Pulmonary association in a case of chronic recurrent multifocal osteomyelitis. Pediatr Pulmonol 1989;7:55-8.

8. Ozbek Z, Makay B, Unsal E, Durak I, Gunes D, Anal $\mathrm{O}$, et al. Conjunctival involvement in chronic recurrent multifocal osteomyelitis. Cornea 2008;27:117-9.

9. Schultz C, Holterhus PM, Seidel A, Jonas S, Barthel M, Kruse K, et al. Chronic recurrent multifocal osteomyelitis in children. Pediatr Infect Dis J 1999;18:1008-13.

10. Hobolth L, Nemery M, Albrectsen J, Hasbak P. Chronic recurrent multifocal osteomyelitis demonstrated by Tc-99m methylene diphosphonate bone scan. Clin Nucl Med 2008;33:61-3.
11. Jurik AG, Egund N. MRI in chronic recurrent multifocal osteomyelitis. Skeletal Radiol 1997;26:230-8.

12. Girschick HJ, Krauspe R, Tschammler A, Huppertz HI. Chronic recurrent osteomyelitis with clavicular involvement in children: diagnostic value of different imaging techniques and therapy with non-steroidal anti-inflammatory drugs. Eur J Pediatr 1998;157:2833.

13. Schilling F, Wagner AD. Azithromycin: an antiinflammatory effect in chronic recurrent multifocal osteomyelitis? A preliminary report. Z Rheumatol 2000;59:352-3. [Abstract]

14. Girschick HJ, Zimmer C, Klaus G, Darge K, Dick A, Morbach H. Chronic recurrent multifocal osteomyelitis: what is it and how should it be treated? Nat Clin Pract Rheumatol 2007;3:733-8.

15. Ishikawa-Nakayama K, Sugiyama E, Sawazaki S, Taki H, Kobayashi M, Koizumi F, et al. Chronic recurrent multifocal osteomyelitis showing marked improvement with corticosteroid treatment. J Rheumatol 2000;27:1318-9.

16. Simm PJ, Allen RC, Zacharin MR. Bisphosphonate treatment in chronic recurrent multifocal osteomyelitis. J Pediatr 2008;152:571-5.

17. Huber AM, Lam PY, Duffy CM, Yeung RS, Ditchfield M, Laxer D, et al. Chronic recurrent multifocal osteomyelitis: clinical outcomes after more than five years of follow-up. J Pediatr 2002;141:198-203. 